\title{
Forest Management Plan for Implementation of a Pilot REDD+ Project for Masito Community Forest Reserve, Kigoma, Tanzania for 2012-2017: Management Prescriptions
}

\author{
Emmanuel Fred Nzunda \\ Department of Forest Resources Assessment and Management, College of Forestry, Wildlife and Tourism, Sokoine University of Agriculture, \\ Morogoro, Tanzania
}

Email address:

nzunda@sua.ac.tz,nzundaef@gmail.com

\section{To cite this article:}

Emmanuel Fred Nzunda. Forest Management Plan for Implementation of a Pilot REDD+ Project for Masito Community Forest Reserve, Kigoma, Tanzania for 2012-2017: Management Prescriptions. International Journal of Natural Resource Ecology and Management. Vol. 6, No. 2, 2021, pp. 42-48. doi: 10.11648/j.ijnrem.20210602.13

Received: April 27, 2021; Accepted: May 14, 2021; Published: May 20, 2021

\begin{abstract}
A forest management plan and particularly the management prescriptions within the plan form the basis for implementation of a forest management project and thereafter the basis for evaluation of performance of the project. The current paper presents management prescriptions for implementation of a pilot REDD+ project for Masito Community Forest Reserve, Kigoma, Tanzania for the period 2012-2017. The description of the management prescriptions is presented under 9 major sections, namely: (1) prescriptions on forest resources; (2) physical resources; (3) human resources; (4) enhancement of community participation; (5) initiatives for revenue generation and sharing; (6) inter-sectoral linkages and co-operation; (7) financial implications; (8) annual plan of operations, and; (9) plan endorsement, monitoring, evaluation and revision. The main prescriptions are that no wood would be harvested from the forest, the forest would be allowed to regenerate only naturally without tree planting, the forest would be managed by the previous REDD+ project arrangements depending on availability of funds. The plan would be approved by the Director, Forestry and Beekeeping Division. The revision of the plan would be done in 2016/17 and would be initiated by the Director of the Jane Goodall Institute REDD+ project.
\end{abstract}

Keywords: Forest Harvesting Plan, Watershed Management, Community Participation, Socio-economic Studies, Silvicultural Operations, Budget

\section{Introduction}

A forest management plan is based on desired goals and includes actions to be taken to achieve these ends [1-3]. The plan itself is a concrete document that landowners and foresters can refer to for guidance while a property is being managed [1]. A planned and managed forest can retain its natural beauty while producing a sustainable supply of lumber, fiber, wildlife, recreation, clean water [1] and other ecosystem services and products such as carbon sequestration and non-wood forest products. Managing one aspect of the resource does not eliminate the possibility of developing others if each is planned in consideration of the others [1]. Forest management planning is an important condition for ecologically sustainable and economically efficient forest use $[4,5]$. The increasing role of forest management planning is based on the obvious need to transition from extensive way of forest management and use of primary natural forests to intensive way of secondary reforested forests management and use [4, 6, 7].

Forest management prescriptions include desired conditions, standards, and goals that are specific to each forest type [8]. For a community forest that is managed for REDD $+{ }^{1}$, these prescriptions have to cover both the ecological dimension as well as the socioeconomic dimension. A forest management plan and particularly the management prescriptions within the plan form the basis for implementation of a forest management project and thereafter the basis for evaluation of performance of the project. This is particularly important in modern times

1 REDD stands for "Reducing Emissions from Deforestation and forest Degradation"; the "+" signifies the role of conservation, sustainable management of forests and enhancement of forest carbon stocks. 
whereby transparency and accountability in management are emphasised for all sectors.

The current paper presents management prescriptions for implementation of a pilot $\mathrm{REDD}+{ }^{2}$ project for Masito Community Forest Reserve (MCFR), Kigoma, Tanzania for the period 2012-2017. The description of the management prescriptions is presented under 9 major sections, namely: (1) prescriptions on forest resources; (2) physical resources; (3) human resources; (4) enhancement of community participation; (5) initiatives for revenue generation and sharing; (6) inter-sectoral linkages and co-operation; (7) financial implications; (8) annual plan of operations, and; (9) plan endorsement, monitoring, evaluation and revision.

\section{Methodology}

The Masito Community Forest Reserve is part of the Masito-Ugalla ecosystem located in Kigoma Region, Tanzania [9]. The major vegetation type of the forest is miombo woodlands [10]. Most of the management prescriptions were arrived at through discussions at a two-day workshop conducted in 2011 to develop the forest management plan. The workshop participants were the author, the Jane Goodall Institute REDD+ project leadership in Kigoma and JUWAMMA $^{3}$ members. Reference was also made to relevant documents as source of data and information for the management prescriptions. The presentation of the results for this paper uses past tense because it is reporting on what was planned in the past. However, the appropriate description of management prescriptions in a forest management plan is in the future tense (e.g. past tense: Forest resource assessment and monitoring conducted would be that aimed....: future tense: Forest resource assessment and monitoring conducted will be that aimed...). The future tense was used in the forest management plan report that was submitted to the Jane Goodall Institute in 2012 of which this paper is an excerpt [11]

\section{Results and Discussion}

\subsection{Prescriptions on Forest Resources}

\subsubsection{Forest Resource Assessment and Monitoring}

Forest resource assessment and monitoring conducted would be that aimed at fulfilling the objective of making MCFR a fundable REDD+ project. Use would be made of a methodology that applies a combination of village-based and external expertise to test the use of 1-km MODIS, 28.5-57-m Landsat MSS, TM and ETM+, 20-m and $2.5 \mathrm{~m}$ SPOT, $60-\mathrm{cm}$ QuickBird and other satellite imagery data combined with field measurements in order to (a) verify past deforestation and carbon emission trends; (b) establish a current forest

2 REDD stands for "Reducing Emissions from Deforestation and forest Degradation"; the "+" signifies the role of conservation, sustainable management of forests and enhancement of forest carbon stocks.

3 JUWAMMA is Swahili for Jumuiya ya Watunza Msitu wa Masito, which in English is Community of Masito Forest Managers. carbon baseline, including determination of leakage and additionality risks evident in the project area; and (c) detect annual changes in carbon sequestration and emission rates in designated forest carbon reserves using field measurements. The outcome would be an independent methodology that can then contribute to the national forest carbon dialogue and support regional and national carbon sequestration and emission monitoring [10, 12, 13].

Particular attention would be paid to assessment of drivers of deforestation and forest degradation, especially fire. Fire, as a driver of unplanned deforestation, would come into play in three areas: the analysis of agents and drivers of deforestation; the estimation of annual estimates of baseline carbon stock changes and emissions from unplanned deforestation in the project area, reference region, and leakage belt; as well as, the derivation of annual deforestation risk maps for location and quantification of baseline and future carbon emissions. Therefore, key goal would be identifying location/quantification of fire impact, and the creation of proxy variables that can be used annually by a spatial model to create annual deforestation risk maps in the 10 years before and over the life of the project. The team would conduct research through detailed literature reviews and complemented by remote sensing analysis of multi-temporal and multi-sensor satellite imagery to determine the effects of fire on carbon accounting. The project area was dominated by miombo forests and woodlands where fire was sometimes necessary to encourage growth of some flora species, but it also experiences significant wildfires resulting from fires deliberately set to clear land for cultivation or grazing. Existing data and observations of the effect of fire on biomass accumulation are inconclusive, and given the significant presence of fire in this ecosystem, it would be impossible to accurately monitor carbon levels without taking fire into account.

Data from the above assessment and monitoring efforts would be used to characterize drivers and agents of deforestation and degradation and leakage risks. Based on the assessment of the drivers of deforestation and forest degradation a spatially explicit model, consistent with Voluntary Carbon Standards (VCS) methodological modules, that describes deforestation risks and provides a without-project baseline projection would be developed. Furthermore, additionality tests to demonstrate that emissions reductions are real and additional would be applied. This would be based on clear definition of project boundaries, reference and leakage areas.

\subsubsection{Harvesting Plan}

MCFR would be managed for enhancement of its carbon stock. There would be no harvesting of wood from MCFR. Only non-wood forest products would be harvested from MCFR in a sustainable way that does not reduce its carbon value. Such products would include dwarf bamboo that was used for basketry, weaving and furniture.

\subsubsection{Silvicultural Systems}

The forest would be allowed to regenerate naturally through protection which would prevent disturbance that affected it in 
the past. There would be no other active silvicultural operation for the sake of improving forest stock. This was because the forest had sufficient natural capacity for regeneration through both sprouting and seeding.

\subsubsection{Boundary Consolidation}

The boundary would be marked using direction trenches. Clearing of the boundary would be performed in May each year, using controlled burning to create a 10-metre wide fire line around the forest. JUWAMMA would oversee the process and would be the main implementer of the activities.

\subsubsection{Forest Protection}

Forest patrols would be performed four times each month by JUWAMMA. The exact schedule of the days for patrol would remain a secret to JUAMMA, to maintain an element of surprise. Furthermore, JUAMMA may conduct any number of surprise patrols, in addition to the schedule four.

\subsubsection{Forest Restocking and Natural Regeneration}

The MCFR and natural forests outside MCFR would be allowed to regenerate naturally. This was because the forests in this landscape had very high ability to regenerate naturally both through seedlings and sprouting. All that was needed was to protect the forests from disturbance that would otherwise hinder natural regeneration.

\subsubsection{Nurseries}

Because there would be no tree planting within and outside MCFR, no nurseries would be needed and thus none would be established.

\subsubsection{Management of Buffer Zones and Corridors}

The buffer zones that fall within village land would be management according to village land use plans (VLUP) [14]. The main guiding principles of the management of these zones are that (1) it was prohibited to enter into Village Land Forest Reserves (VLFR) and cut trees, build, cultivate, debark trees and dig holes; (2) it was prohibited to burn forested areas; (3) it was prohibited to harvest legally protected tree species even outside VLFR; (4) it was prohibited to use VLFR for grazing or as a route for animals without permission and; (5) it was mandatory to participate in firefighting efforts whenever there was a wildfire within the landscape. To reinforce these principles, a specified fine would be charged to culprits.

\subsubsection{Watershed Areas Management and Soil Conservation}

Watershed areas management and soil conservation would be conducted according to VLUP whereby (1) it was prohibited to use fire as a means of farm clearing; (2) it was mandatory for farmers to use appropriate farming techniques that enhance soil and water conservation; (3) it was prohibited to fish from fish breeding areas in rivers and Lake Tanganyika; (4) it was prohibited to fish using illegal fishing gear; (5) it was prohibited to cut trees, build, cultivate, graze or use as water drinking areas for animals or spoil in anyway all the water sources and springs within the landscape; (6) allowable distance for residence was $500 \mathrm{~m}$ from Lake Tanganyika, 200 $\mathrm{m}$ from springs, $100 \mathrm{~m}$ from large rivers, $60 \mathrm{~m}$ from small rivers and $30 \mathrm{~m}$ from wells. A prescribed fine would be charged against anyone who trespasses these principles.

\subsection{Physical Resources}

The office house in Kigoma town would continue to be hired for continued operation of the managerial functions for MCFR. The vehicle would receive service for maintenance so as to function properly. Batteries and replacement memory cards would be bought for Android phones and GPS units. To facilitate forest patrol by FM, bicycles would be bought.

\subsection{Human Resources}

\subsubsection{Staff}

One Forest Officer and one Monitoring and Evaluation Officer would be employed. These would be holders of either Bachelor's degrees or Diploma's. Daily field activities would be performed by JUWAMMA and other villagers.

\subsubsection{Training}

Training would continue to focus on increasing awareness of the local communities on the negative effects of uncontrolled forest utilisation, benefits of proper forest management, alternative income generating activities and increasing the capacity of JUWAMMA and the community at large to participate in management of MCFR by increasing their technical knowledge relevant for forest management. Thus, there would be more training on forest protection, modern beekeeping, good governance, participatory mapping, carbon assessment and carbon sequestration and storage processes, carbon marketing and REDD and business management, customer care and marketing skills. The training would increase the number of people trained in these fields and increase the depth of training for those who had first level training.

\subsection{Enhancement of Community Participation}

\subsubsection{Community Organisations and Institutions}

JUWAMMA would continue to lead the community in management of MCFR. According to JUWAMMA constitution, there would be four JUWAMMA General Council meetings per year, except when occasion demands otherwise. All General Council meetings would be conducted after meetings of member villages so as to allow member villages to contribute ideas raised from the village meetings. General Council meetings would be attended by five members from Village Environmental Committees of member villages, Village Executive Officers, Village Chairpersons, Hamlet Chairpersons and invited guests depending on need and the capacity of JUWAMMA. However, only the five representatives from Village Environmental Committees would vote, whereupon every member would have one vote.

The General Council was the one with final decision on issues related to JUWAMMA. The quorum for validity of decisions would be two-thirds of the membership of the General Council of JUWAMMA. An emergency General Council meeting would be convened for deliberating on 
matters that need urgent decision. The quorum for the meeting would be one-third of the membership. All meetings of the General Council meetings shall be announced at least 14 days before the day of the meeting via a letter that would stipulate the agenda and would be signed by the chairperson and secretary of JUWAMMA.

All normal meetings of the General Council would had the following roles: (i) to remove or add an item of the agenda after going through the agenda, (ii) to receive reports of the activities of the committees of JUWAMMA covering the period since last report, (iii) to discuss issues and decide through open ballot in case there was a matter needs voting to decide and, (iv) to receive financial report for the respective period. The annual general meeting of the General Council would (i) receive report of income and expenditure for the year and endorse estimates of income and expenditure for the next year, (ii) receive annual report of performance and, (iii) endorse expenditure of money for amounts that are beyond what the General Committee can.

\subsubsection{Instruments to Facilitate Community Participation}

Bylaws and Joint Management Agreement between JUWAMMA and FBD would be formalised. These would have to be prepared and endorsed by the General Council of JUWAMMA with necessary facilitation.

\subsubsection{Extension Services}

Training would continue to be provided. In addition to training awareness would be enhanced through the use of posters, radio programmes and TV and video programmes and drama. Radio Free Africa and Star TV would be used for radio and TV programmes whereas Mapigo Saba group would continue to serve with the drama issues.

\subsubsection{Socio-economic Studies}

Socio-economic studies that determine the rate of adoption and factors that influence adoption of issues that are taught by the project, especially modern beekeeping would be conducted. Towards the end of the five year period of implementation of this plan, a follow up socio-socio-economic study would be conducted to examine changes against the baseline information [15] on behaviour regarding forest degradation and loss, carbon emission reduction risks, opportunities and benefits for REDD Project in Masito Ugalla Ecosystem.

\subsection{Initiatives for Revenue Generation and Sharing}

The main revenue source envisaged for MCFR was that from carbon credits under REDD + scheme. The procedures needed (according to Voluntary Carbon Standards (VCS) guidelines and steps to have MCFR under full-swing REDD+ programme would be finalised so that the expected income would be materialised.

\subsection{Inter-sectoral Linkages and Co-operation}

The project would continue to work closely with various sectors of the Kigoma District Council (KDC). In particular, the district Beekeeping Sector would continue to facilitate training on modern beekeeping and supply of needed beekeeping gear.

\subsection{Financial Implications}

The budget estimates are provided for the activities for implementation of the management plan (Table 1). The estimates are based on what was expended by the existing project.

Table 1. Budget For Implementation of Masito Community Forest Reserve Management Plan 2012/13 To 2016/2017.

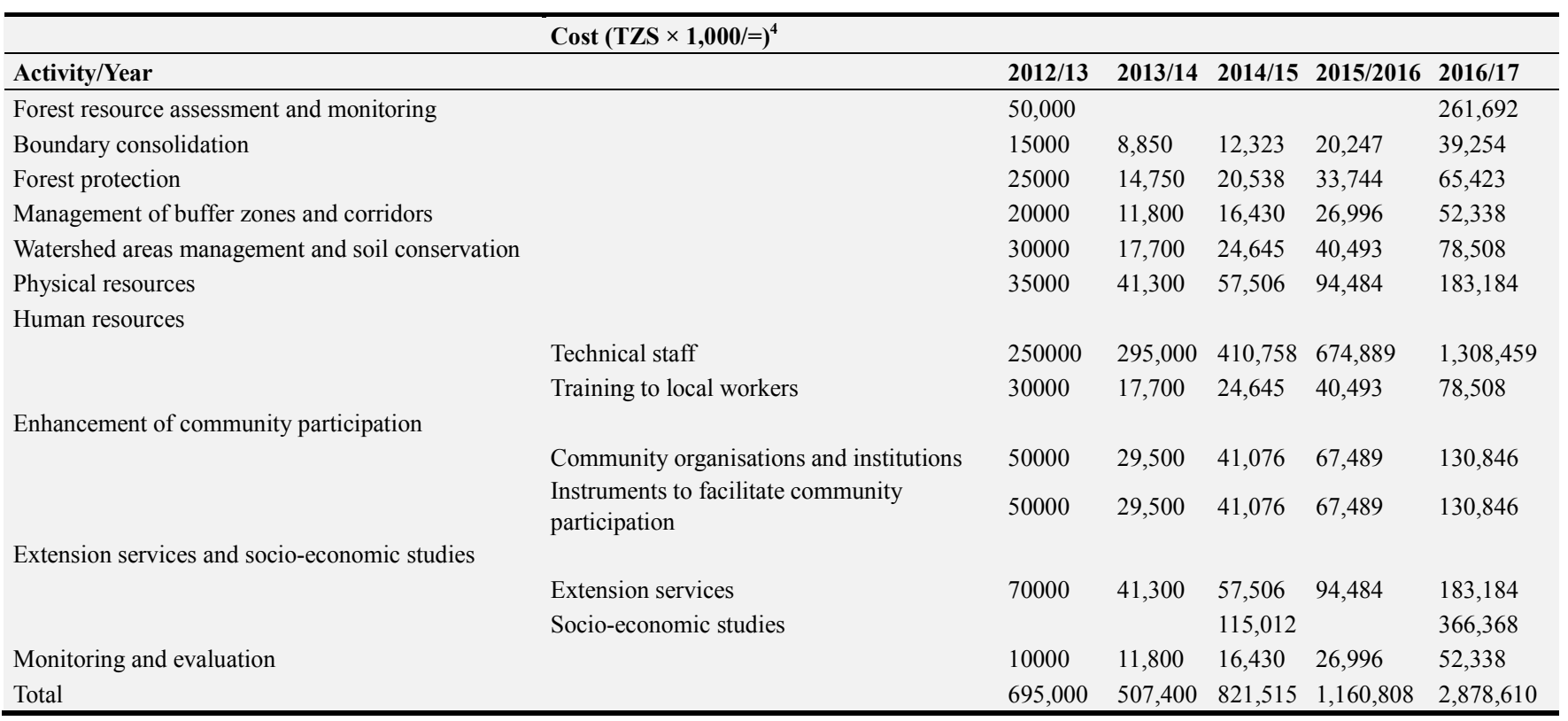

$41 \mathrm{US} \$=1,575.00 \mathrm{TZS}$ (Tanzania Shilling) as at $31^{\text {st }}$ December 2012 
Projections for future amounts were made using a compound interest rate of $18 \%$, which was approximately the inflation rate of the Tanzania shilling. The money to finance these activities would have to come from sources other than the MCFR forest itself until some funds start coming from the REDD+ sale of carbon credits.

\subsection{Annual Plan of Operations}

The activities that were expected to be performed for each year are presented in Table 2. Forest resource assessment and monitoring was on going and was expected to be finished by
2013. Towards the end of the planning period in 2016/17, another round of forest assessment would be needed to determine the impact of the implementation of the REDD+ project. Boundary consolidation, forest protection, management of buffer zones and corridors, watershed areas management and soil conservation, physical resources, human resources, enhancement of community participation, extension services and monitoring and evaluation are issues that would need attention in each year throughout the planning period.

Table 2. Ganntt chart showing annual plan of operation for management of Masito Community Forest Reserve, 2012/13 - 2016/17.

\begin{tabular}{|c|c|c|c|c|c|c|}
\hline \multirow[b]{2}{*}{ Activity } & & \multicolumn{4}{|c|}{ Year } & \multirow[b]{2}{*}{ 2016/17 } \\
\hline & & $2012 / 13$ & $2013 / 14$ & $2014 / 15$ & $2015 / 2016$ & \\
\hline Forest resource assessment and monitoring & & $\mathrm{X}$ & & & & \\
\hline Boundary consolidation & & $\mathrm{X}$ & $\mathrm{X}$ & $\mathrm{X}$ & $\mathrm{X}$ & $\mathrm{X}$ \\
\hline Forest protection & & $\mathrm{X}$ & $\mathrm{X}$ & $\mathrm{X}$ & $\mathrm{X}$ & $\mathrm{X}$ \\
\hline Management of buffer zones and corridors & & $\mathrm{X}$ & $\mathrm{X}$ & $\mathrm{X}$ & $\mathrm{X}$ & $\mathrm{X}$ \\
\hline $\begin{array}{l}\text { Watershed areas management and soil } \\
\text { conservation }\end{array}$ & & $\mathrm{X}$ & $\mathrm{X}$ & $\mathrm{X}$ & $\mathrm{X}$ & $\mathrm{X}$ \\
\hline Physical resources & & $\mathrm{X}$ & $\mathrm{X}$ & $\mathrm{X}$ & $\mathrm{X}$ & $\mathrm{X}$ \\
\hline \multicolumn{7}{|l|}{ Human resources } \\
\hline & Technical staff & $\mathrm{X}$ & $\mathrm{X}$ & $\mathrm{X}$ & $\mathrm{X}$ & $\mathrm{X}$ \\
\hline & Training to local workers & $\mathrm{X}$ & $\mathrm{X}$ & $\mathrm{X}$ & $\mathrm{X}$ & $\mathrm{X}$ \\
\hline \multicolumn{7}{|l|}{ Enhancement of community participation } \\
\hline & Community organisations and institutions & $\mathrm{X}$ & $\mathrm{X}$ & $\mathrm{X}$ & $\mathrm{X}$ & $\mathrm{X}$ \\
\hline & Instruments to facilitate community participation & $\mathrm{X}$ & $\mathrm{X}$ & $\mathrm{X}$ & $\mathrm{X}$ & $\mathrm{X}$ \\
\hline & Extension services & $\mathrm{X}$ & $\mathrm{X}$ & $\mathrm{X}$ & $\mathrm{X}$ & $\mathrm{X}$ \\
\hline & Socio-economic studies & & & & $\mathrm{X}$ & $\mathrm{X}$ \\
\hline Monitoring and evaluation & & $\mathrm{X}$ & $\mathrm{X}$ & $\mathrm{X}$ & $\mathrm{X}$ & $\mathrm{X}$ \\
\hline
\end{tabular}

Table 3. Aspects of monitoring and evaluation for Masito Community Forest Reserve.

\begin{tabular}{|c|c|c|c|c|c|}
\hline \multicolumn{6}{|c|}{ Year } \\
\hline Activity & $2012 / 13$ & $2013 / 14$ & $2014 / 15$ & $2015 / 2016$ & $2016 / 17$ \\
\hline $\begin{array}{l}\text { Forest resource } \\
\text { assessment and } \\
\text { monitoring }\end{array}$ & $\begin{array}{l}\text { Information on carbon } \\
\text { stocks }\end{array}$ & & & & $\begin{array}{l}\text { Information on effect of } \\
\text { REDD+ project on } \\
\text { carbon stocks }\end{array}$ \\
\hline Boundary consolidation & Whole boundary cleared & Whole boundary cleared & Whole boundary cleared & $\begin{array}{l}\text { Whole boundary } \\
\text { cleared }\end{array}$ & Whole boundary cleared \\
\hline Technical staff & $\begin{array}{l}\text { Employment of forester } \\
\text { and monitoring and } \\
\text { evaluation staff }\end{array}$ & & & & \\
\hline $\begin{array}{l}\text { Training to local } \\
\text { workers }\end{array}$ & $\begin{array}{l}\text { Training on modern } \\
\text { beekeeping }\end{array}$ & $\begin{array}{l}\text { Training on modern } \\
\text { beekeeping }\end{array}$ & $\begin{array}{l}\text { Training on modern } \\
\text { beekeeping }\end{array}$ & $\begin{array}{l}\text { Training on modern } \\
\text { beekeeping }\end{array}$ & $\begin{array}{l}\text { Training on modern } \\
\text { beekeeping }\end{array}$ \\
\hline $\begin{array}{l}\text { Community } \\
\text { organisations and } \\
\text { institutions }\end{array}$ & $\begin{array}{l}\text { JUWAMMA meetings } \\
\text { conducted as scheduled }\end{array}$ & $\begin{array}{l}\text { JUWAMMA meetings } \\
\text { conducted as scheduled }\end{array}$ & $\begin{array}{l}\text { JUWAMMA meetings } \\
\text { conducted as scheduled }\end{array}$ & $\begin{array}{l}\text { JUWAMMA meetings } \\
\text { conducted as } \\
\text { scheduled }\end{array}$ & $\begin{array}{l}\text { JUWAMMA meetings } \\
\text { conducted as scheduled }\end{array}$ \\
\hline $\begin{array}{l}\text { Instruments to facilitate } \\
\text { community } \\
\text { participation }\end{array}$ & & $\begin{array}{l}\text { Formalisation of bylaws } \\
\text { and management } \\
\text { agreements }\end{array}$ & & & \\
\hline Extension services & $\begin{array}{l}\text { Extension activities } \\
\text { conducted }\end{array}$ & $\begin{array}{l}\text { Extension activities } \\
\text { conducted }\end{array}$ & $\begin{array}{l}\text { Extension activities } \\
\text { conducted }\end{array}$ & $\begin{array}{l}\text { Extension activities } \\
\text { conducted }\end{array}$ & $\begin{array}{l}\text { Extension activities } \\
\text { conducted }\end{array}$ \\
\hline Socio-economic studies & & & $\begin{array}{l}\text { Adoption patterns and } \\
\text { factors }\end{array}$ & & $\begin{array}{l}\text { Changes in } \\
\text { socio-economic } \\
\text { characteristics }\end{array}$ \\
\hline $\begin{array}{l}\text { Monitoring and } \\
\text { evaluation }\end{array}$ & $\begin{array}{l}\text { Technical and financial } \\
\text { reports of } \\
\text { implementation }\end{array}$ & $\begin{array}{l}\text { Technical and financial } \\
\text { reports of } \\
\text { implementation }\end{array}$ & $\begin{array}{l}\text { Technical and financial } \\
\text { reports of } \\
\text { implementation }\end{array}$ & $\begin{array}{l}\text { Technical and financial } \\
\text { reports of } \\
\text { implementation }\end{array}$ & $\begin{array}{l}\text { Technical and financial } \\
\text { reports of } \\
\text { implementation }\end{array}$ \\
\hline
\end{tabular}


Technical and financial reports from monitoring and evaluation would be produced for every six-month period. Socio-economic studies in $2014 / 15$ would be needed to determine patterns and factors of adoption of issues that the communities were trained on such as beekeeping and business management while those at the end of the planning period in $2016 / 17$ would be needed to determine the overall changes in socio-economic characteristics for comparison with the baseline information [15].

\subsection{Plan Endorsement, Monitoring, Evaluation and Revision}

\subsubsection{Activity Schedule}

Aspects of monitoring and evaluation are summarised in Table 3. Some of the implementation aspects (i.e. activities) would be monitored and evaluated every year while others would be evaluated only during the years for which they are expected to be implemented.

\subsubsection{Constraints}

The main constraint to the implementation of the plan was that of availability of funds after the end of the current pilot REDD+ project, which was December 2012. The other constrains are distance, weather conditions, uncertainty of security (due to bandits) and social calamities which may influence clearing of forest boundary and forest patrols. Overall, the continued political stability and peace in the country in general was necessary for the successful implementation of the proposed plan.

\subsubsection{Planning Period, Amendments and Revision}

The plan covers five years $2012 / 13$ - 2016/17. The plan would be approved by the Director, Forestry and Beekeeping Division. The revision of the plan would be done in 2016/17 and would be initiated by the Director of the Jane Goodall Institute (JGI) REDD+ project. The revisions would also be endorsed by the Director, Forestry and Beekeeping Division.

\section{Conclusions}

Forest resource assessment and monitoring conducted would be that aimed at fulfilling the objective of making MCFR a fundable REDD+ project. MCFR would be managed for enhancement of its carbon stock. There would be no harvesting of wood from MCFR. Only non-wood forest products would be harvested from MCFR in a sustainable way that does not reduce its carbon value. The forest would be allowed to regenerate naturally through protection which would prevent disturbance that affected it in the past. The boundary would be marked using direction trenches. Clearing of the boundary would be performed in May each year, using controlled burning to create a 10 -metre wide fire line around the forest. Forest patrols would be performed four times each month by JUWAMMA. Because there would be no tree planting within and outside MCFR, no nurseries would be needed and thus none would be established. The buffer zones and watershed areas that fall within village land would be management according to village land use plans. The office house in Kigoma town would continue to be hired for continued operation of the managerial functions for MCFR. One Forest Officer and one Monitoring and Evaluation Officer would be employed. Training would continue to focus on increasing awareness of the local communities on the negative effects of uncontrolled forest utilisation, benefits of proper forest management, alternative income generating activities and increasing the capacity of JUWAMMA and the community at large to participate in management of MCFR by increasing their technical knowledge relevant for forest management. JUWAMMA would continue to lead the community in management of MCFR according to JUWAMMA constitution. Bylaws and Joint Management Agreement between JUWAMMA and FBD would be formalised. Training would continue to be provided. In addition to training awareness would be enhanced through the use of posters, radio programmes and TV and video programmes and drama. Socio-economic studies would be conducted to determine changes in the society over time towards the end of the implementation of the project. The main revenue source envisaged for MCFR was that from carbon credits under REDD+ scheme. The project would continue to work closely with various sectors of the KDC. The money to finance the prescribed activities would have to come from sources other than the MCFR forest itself until some funds start coming from the REDD+ sale of carbon credits. Boundary consolidation, forest protection, management of buffer zones and corridors, watershed areas management and soil conservation, physical resources, human resources, enhancement of community participation, extension services and monitoring and evaluation are issues that would need attention in each year throughout the planning period. Other activities would be performed at specific times during the planning period. Some of the implementation aspects would be monitored and evaluated every year while others would be evaluated only during the years for which they are expected to be implemented. The constraints to implementation of the project are uncertainty of availability of funds, distance, weather conditions, uncertainty of security (due to bandits) and social calamities which may influence clearing of forest boundary and forest patrols. Overall, the continued political stability and peace in the country in general was necessary for the successful implementation of the proposed plan. The plan covers five years 2012/13 - 2016/17. The plan would be approved by the Director, Forestry and Beekeeping Division. The revision of the plan would be done in 2016/17 and would be initiated by the Director of the JGI REDD+ project.

\section{Acknowledgements}

The author thanks the villagers who attended the workshop that discussed the issues prescribed in the forest management plan. The author also thanks the Jane Goodall Institute for financing the forest management planning exercise. 


\section{References}

[1] WDNR, "Multiple Benefits From Forest Management," 2021. [Online]. Available: www.dnr.state.wi.us.

[2] L. Dennis-Perez and M. Kuhns, "Forest Management Planning," Utah Forest Facts, 2012. https://forestry.usu.edu/files/forest-management-planning.pdf.

[3] E. F. Nzunda, "Discrepancies between targets and achievements in industrial forest production and export in Tanzania," For. Stud. China, vol. 14, no. 3, 2012, doi: 10.1007/s11632-012-0307-y.

[4] V. Akishin, "Forest planning as the most important aspect of sustainable forest management. ERSA conference papers ersa14p569, European Regional Science Association.," 2014.

[5] ATIBT, "Study of a Practical Forest Management Plan for natural tropical production forests in Africa," 2007. [Online]. Available:

https://www.atibt.org/wp-content/uploads/2017/06/Volet-I-ang lais.pdf.

[6] WDNR, "CHAPTER 10 Forest Management Planning," in Management, Wisconsin Department of Natural Resources, 2020.

[7] H. Soman, A. R. Kizha, and B. E. Roth, "Impacts of silvicultural prescriptions and implementation of best management practices on timber harvesting costs," Int. J. For. Eng., vol. 30, no. 1, pp. 14-25, 2019, doi: 10.1080/14942119.2019.1562691.

[8] USDA, "Chapter 3: Management Prescriptions," in Land and Resource Management Plan: Chattahoochee-Oconee National Forests, United States Department of Agriculture Forest Service Southern Region, 2004.
[9] J. E. Makunga and S. B. Misana, "The Extent and Drivers of Deforestation and Forest Degradation in Masito-Ugalla Ecosystem, Kigoma Region, Tanzania," Open J. For, vol. 07, no. 02, pp. 285-305, 2017, doi: 10.4236/ojf.2017.72018.

[10] E. Zahabu, "Ground Forest Carbon Assessment of the Masito Ugalla Ecosystem Pilot Area. A consultancy report prepared for the Jane Goodall Institute - Tanzania, Kigoma.,” 2011.

[11] E. F. Nzunda, "Forest management plan for implementation of a pilot REDD+ project for Masito Community Forest Reserve, Kigoma, Tanzania. Submitted to The Jane Goodall Institute Masito REDD+ Pilot Project, Kigoma, Tanzania.," 2012.

[12] E. Zahabu, "Training of Trainers on JGI REDD Readiness project. Report for the JGI REDD Readiness Workshop Kigoma, Tanzania April 5-8, 2011. JGI REDD Readiness project in Masito-Ugala.," 2011.

[13] JGI, "Building REDD Readiness in the Masito Ugalla Ecosystem Pilot Area in Support of Tanzania's National REDD Strategy. A proposal submitted by the Jane Goodall Insititute (JGI) to: Royal Norwegian Embassy in Tanzania and the Government of Tanzania's National,” 2009.

[14] KDC, "Mpango wa matumizi bora ya ardhi kijiji cha Lyabusende, kata ya Sunuka, Tarafa ya Ilagala, wilaya ya Kigoma, mkoa wa Kigoma (2008-2028). Imewezeshwa na Kigoma District Council. Imefadhiliwa na Jane Goodall Insitute.," 2009.

[15] ACHRID, "Baseline Assessment of Behaviour Change Regarding Forest Degradation and Loss, Carbon Emission Reduction Risks, Opportunities and Benefits for REDD Project in Masito Ugalla Ecosystem Kigoma, Tanzania. Report submitted to JGI, Kigoma.," 2011. 